\title{
KAJIAN KANDUNGAN LOGAM BERAT MERKURI (Hg) PADA KERANG AIR TAWAR (Anodonta sp) DI KAWASAN HILIR SUB DAS KRUENG MEUREUBO, ACEH BARAT
}

\section{STUDY OF HEAVY METAL CONTENT OF MERCURY (HG) IN FRESHWATER SHELLS (Anodonta Sp) IN THE DOWNSTREAM SUB DAS KRUENG MEUREUBO REGION, WEST ACEH}

\author{
Munandar $^{1)}$, Alwis Alamsyah ${ }^{1)}$ \\ ${ }^{1}$ Program Studi Perikanan, Fakultas Perikanan dan Ilmu Kelautan, Universitas Teuku Umar, Aceh Barat \\ Korespondensi: munandar@utu.ac.id
}

\begin{abstract}
One source of mercury pollution came from gold mining was done by the community from gold processing through amalgamation. Heavy metals that present in the waters will undergo deposition process and accumulate in marine animals then end up in humans. Meureubo upstream region is one of the locations that still carried out the gold mining activities used mercury. That condition is one potential factor that can contaminate the waters. This study was conducted in October-November 2014. Sampling was taked in Meureubo River and the mercury content analysis was carried out in the Laboratory of Research and Standardization Industry (Baristan) Banda Aceh. The laboratory analysis results showed that the total mercury $(\mathrm{Hg})$ of heavy metals in the freshwater mussels samples (Anodonta sp) on RP station is $0,074 \mathrm{ppm}$, PP illustrates $0,042 \mathrm{ppm}$ and PA confirms $0.304 \mathrm{ppm}$. Furthermore, the total mercury $(\mathrm{Hg})$ of heavy metals in the sample freshwater on RP station around $0.0005085 \mathrm{mg} / \mathrm{l}$, PP 0.0001792 $\mathrm{mg} / \mathrm{l}$ and PA $0.0006711 \mathrm{mg} / \mathrm{l}$. The results showed that the samples of freshwater mussels (Anodonta sp) and the water samples which taken at three stations (Rantau Panjang, Pasi Pinang, Pasi Aceh) were positive for mercury ( $\mathrm{Hg})$.
\end{abstract}

Keywords: Aquatic organisms, Mercury, Pollution

\section{Pendahuluan}

Pencemaran adalah perubahan sifat fisika, kimia, dan biologi yang tidak dikehendaki pada tanah, udara, dan air. Perubahan tersebut dapat menimbulkan bahaya bagi kehidupan manusia atau organisme lainnya. Pencemaran terjadi apabila terdapat ganguan dalam daur materi yaitu apabila laju produksi suatu zat melebihi laju pembuangan atau penggunaan zat tersebut (Umar, 2001).

Organisme yang mengalami dampak secara langsung dari pengaruh limbah atau pencemaran terhadap badan air adalah organisme yang tergolong dalam kelompok akuatik. Apabila suatu limbah yang berupa bahan pencemar masuk kesuatu lokasi maka akan terjadi perubahan pada lokasi tersebut, perubahan dapat terjadi pada organisme yang hidup pada lokasi serta lingkungan yang berupa faktor kimia dan fisika (Sartika, 2002). Kondisi alam sebenarnya dalam keseimbangan yang beraturan, membentuk mata rantai yang berhubungan satu sama lainnya, sehingga apabila salah satu komponennya terganggu maka akan berpengaruh pada komponen yang lainnya. 
Logam berat merupakan salah satu bahan pencemar yang berbahaya karena bersifat toksik jika dalam jumlah besar dan dapat mempengaruhi berbagai aspek dalam perairan baik aspek ekologis maupun aspek biologi (Umar, 2001). Logam- logam yang mencemari perairan laut banyak jenisnya, diantaranya yang cukup banyak adalah kadmium $(\mathrm{Cd})$ dan logam timbal $(\mathrm{Pb})$. Kedua logam tersebut bergabung bersama dengan merkuri $(\mathrm{Hg})$ sebagai the big three heavy metal yang memiliki tingkat bahaya tertinggi pada kesehatan manusia, selain itu ketiga logam tersebut yang paling sering ditemukan sebagai bahan pencemar logam yang ada di alam (Suhendrayatna, 2001).

Keberadaan merkuri di lingkungan dapat berasal dari berbagai aktivitas manusia yang menghasilkan limbah merkuri sehingga konsentrasi merkuri di lingkungan dapat meningkat (Purnawan et al, 2013). Salah satu aktifitas manusia yang dapat merusak lingkungan adalah proses pengolahan emas secara amalgasi. Pada proses amalgamasi emas yang dilakukan oleh rakyat secara tradisional, merkuri dapat terlepas ke lingkungan pada tahap pencucian dan penggarangan. Pada proses pencucian, limbah yang umumnya masih mengandung merkuri dibuang langsung ke badan air. Hal ini disebabkan merkuri tersebut tercampur/terpecah menjadi butiran-butiran halus yang sifatnya sukar dipisahkan pada proses penggilingan yang dilakukan bersamaan dengan proses amalgamasi, sehingga pada proses pencucian merkuri dalam ampas terbawa masuk ke sungai. (Widhiyatna, 2005).

Sungai Mereubo merupakan suatu aliran sungai yang hulunya di Pante Ceureumen yang masyarakatnya melakukan kegiatan dulang emas secara tradisional. Logam berat yang ada dalam perairan akan mengalami proses pengendapan dan akan terakumulasi dalam biota laut yang ada dalam perairan baik melalui insang maupun melalui rantai makanan dan akhirnya akan sampai pada manusia. Fenomena ini dikenal sebagai bioakumulasi atau biomagnifikasi. Menurut Fauziah et al. (2012), jenis kerangkerangan merupakan jenis organisme khas yang dapat mengakumulasi logam berat, dikarenakan kerang mempunyai mobilitas yang rendah sehingga adanya logam berat di dalam tubuhnya dipandang dapat mewakili keberadaan logam berat yang terdapat dihabitatnya.

Menurut Ermin et al. (2008) menyatakan bahwa lingkungan perairan, seperti sungai dan laut, akan terakumulasi melalui proses magnifikasi biologis dalam biota air atau laut, dan terserap dalam sedimen, serta membahayakan hasil perikanan. Salah satunya adalah kerang (Anodonta sp), bersifat filter feeder yang hidup menetap, sehingga dapat menggambarkan keadaan yang sebenarnya dari tempat hidupnya. Melalui penelitian ini, peneliti akan mengkaji tingkat pencemaran merkuri $(\mathrm{Hg})$ di kawasan hilir sub DAS Krueng Meureubo dengan menggunakan kerang (Anodonta sp) sebagai indikator biologi dan tingkat konsentrasi merkuri $(\mathrm{Hg})$ pada kawasan hilir sub DAS Krueng Meureubo. 


\section{Metode Penelitian}

Penelitian ini dilaksanakan pada bulan Oktober-November 2014. Tahapan penelitian terdiri dari dua tahapan, yaitu pengambilan sampel dan pengukuran kandungan logam berat.

\subsection{Pengambilan Sampel}

Pengambilan sampel dilakukan di kawasan hilir sub DAS Krueng Meureubo dan analisis kandungan Merkuri dilakukan di Laboratorium Balai Riset dan Standardisasi Industri (BARISTAN) Banda Aceh. Titik pengambilan sampel pada tiga lokasi berbeda yaitu Pasi Pinang, Rantao Panjang, dan Pasi Aceh. Peta penelitian dapat dilihat pada Gambar 1 berikut :

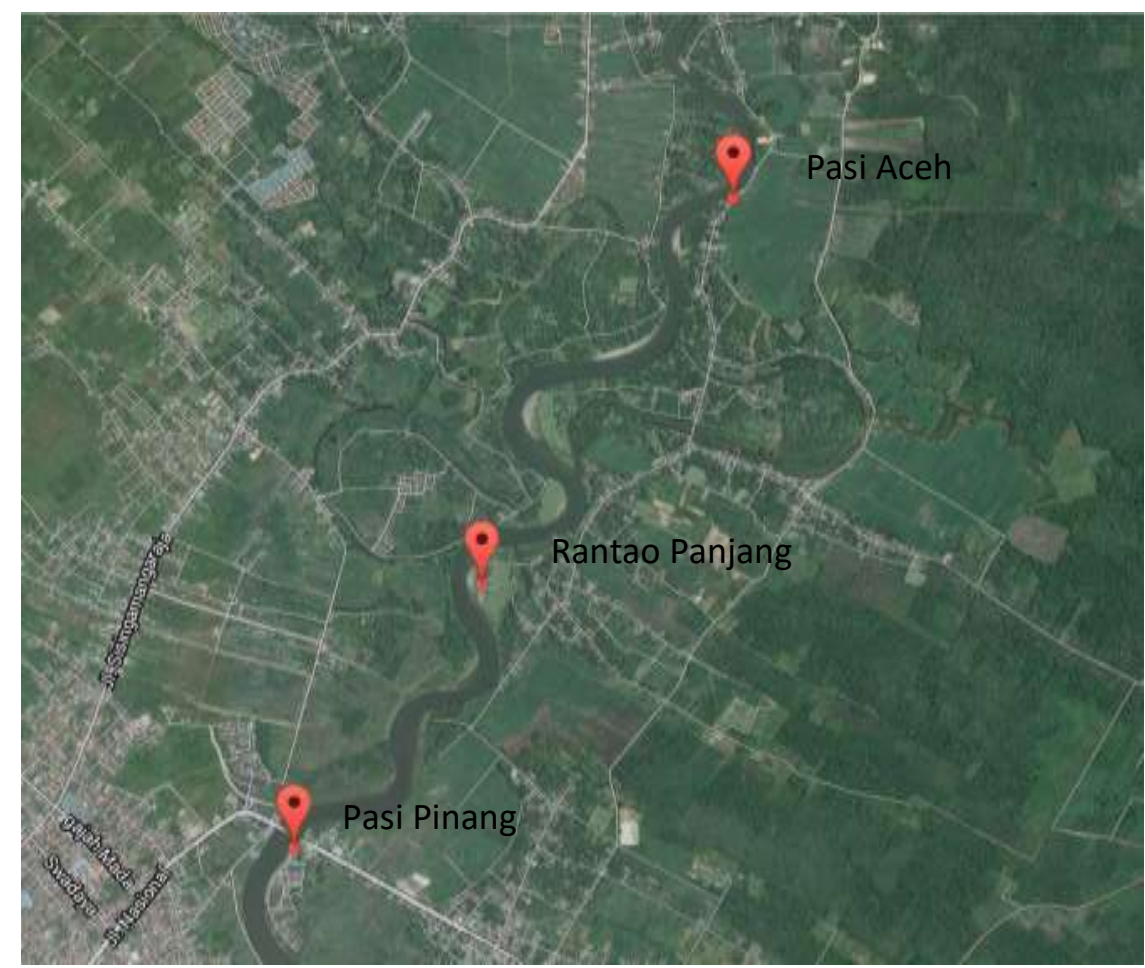

Gambar 1. Peta Lokasi (Sumber Bappeda Aceh Barat)

Sampel kerang diambil sendiri oleh peneliti di kawasan hilir Sub DAS Krueng Meureubo yang dibagi menjadi 3 stasiun yaitu di desa : Pasi Pinang, Ranto Panjang, dan Pasi Aceh. Dasar pengambilan sampel di tiga tempat berbeda karena:

1. Pasi pinang: merupakan wilayah Daerah Aliran Sungai (DAS) terakhir yang di aliri dan apabila sampai pada titik terjauh masih tercemar merkuri maka terdapat kemungkinan biota sungai dari sekian desa pasi pinang tersebut mengalami pencemaran merkuri $(\mathrm{Hg})$.

2. Ranto panjang; merupakan tempat yang paling banyak ditemukannya biota sungai (kerang) oleh masyarakat sekaligus tempat penjualan kerang.

3. Pasie Aceh; sangat berdekatan dengan peninggalan penambangan emas sertatempat penjualan kerang oleh masyarakat. 


\subsection{Pengukuran Logam Berat}

Pengambilan sampel disetiap desa minimal tiga titik dan jumlah kerang 5-10 ekor pada setiap titik. Sampel kemudian dianalisis di Laboratorium Balai Kesehatan Banda Aceh. Metode pengukuran logam berat menggunakan Atomic Absorption Spectrophotometry (AAS) yaitu pengukuran berdasarkan penguapan larutan sampel, kemudian logam yang terkandung di dalamnya diubah menjadi atom bebas (Hutagalung, 1985). Parameter utama yang diamati adalah konsentrasi logam berat merkuri (Hg) pada kerang dan perairan Krueng Meurebo.

Data yang diperoleh dari hasil analisis logam berat dibandingkan dengan tabel standar normal konsentrasi ketentuan baku mutu kandungan logam berat pada air menurut standar Indonesia yang dilaporkan oleh Palupi dan WHO. Nilai indeks konsentrasi merkuri (Hg) untuk air tawar adalah $0.08 \mathrm{ppm}$. Sedangkan kadar maksimum cemaran logam berat merkuri $(\mathrm{Hg})$ yang diizinkan dan boleh dikonsumsi pada berbagai jenis pangan secara umum 0,1 ppm (Wahyu et al. 2008).

\section{Hasil dan Pembahasan}

Sampel kerang dan air pada setiap stasiun di kawasan hilir sub DAS diukur kandungan logam beratnya menggunakan metode uji Atomic Absorption Spectrophotometry (AAS). Berdasarkan hasil analisis di Laboratorium Balai Riset dan Standarisasi Industri Banda Aceh, kerang air tawar (Anodonta sp) dan sampel air yang ada di 3 stasiun kawasan Meureubo yang terindentifikasi adanya kandungan merkuri (Hg). Hasil uji AAS terhadap kandungan merkuri $(\mathrm{Hg})$ pada sampel kerang (Anodonta sp) di kawasan hili sub DAS Kreung Meureubo dapat dilihat pada Tabel 1.

Tabel 1 Hasil uji Hg pada kerang air tawar (Anodonta sp) di Krueng Meureubo

\begin{tabular}{ccccc}
\hline Kode & \multirow{2}{*}{ Nama Tempat } & \multicolumn{2}{c}{ Penggunaan Merkuri (Hg) } & \multirow{2}{*}{ Frekuensi } \\
\cline { 3 - 4 } Sampel & & Negatif & Positif & \\
\hline Stasiun & Rantau Panjang & & $\sqrt{ }$ & 0,074 \\
Stasiun & Pasie Pinang & & $\sqrt{ }$ & 0,042 \\
Stasiun & Pasie Aceh & & $\sqrt{ }$ & 0,304 \\
\hline
\end{tabular}

Kerang air tawar dari masing-masing titik pengambilan sampel terdeteksi mengandung logam berat merkuri $(\mathrm{Hg})$. Nilai konsentrasi $\mathrm{Hg}$ pada kerang air tawar yang diambil dari stasiun Rantau Panjang dan Pasie Pinang masih di bawah batas baku mutu yang ditetapkan oleh WHO, yaitu di bawah 0,1 ppm. Sedangkan kerang air tawar yang diambil pada stasiun Pasie Aceh memiliki kandungan merkuri yang telah melewati batas baku mutu WHO, yaitu sebesar 0,304 ppm. Berdasarkan nilai tersebut maka dapat dikatakan bahwa kandungan merkuri pada kerang (Anodonta sp) yang berasal dari stasiun Pasie Aceh sudah melewati batas maksimum kandungan logam berat layak konsumsi, batas baku mutu untuk merkuri $(\mathrm{Hg})$ tersebut adalah 0,1 ppm (Wahyu et al. 2008). 
Kerang air tawar (Anodonta sp) yang terdapat pada stasiun III memiliki kandungan merkuri $(\mathrm{Hg})$ yang tertinggi diantara stasiun yang lain. Tingginya persentasi logam berat merkuri $(\mathrm{Hg})$ pada stasiun III Pasie Pinang dikarenakan kaki aliran hilir sub DAS krueng Meureubo memasuki titik stasiun III Pasie Aceh. Pada daerah hulu aliran sungai Meurebo terdapat kegiatan pengolahan tambang emas tradisonal dan adanya penambangan batu bara.

Pengukuran kandungan logam berat merkuri (Hg) juga dilakukan pada sampel air dari masing-masing stasiun pengambilan sampel. Kandungan merkuri $(\mathrm{Hg})$ dari masing-masing stasiun dapat dilihat pada Tabel 2. Adapun stasiun sampel air tawar di wilayah kawasan Hilir sub DAS Krueng Meureubo dapat dilihat pada tabel 2 di bawah ini.

Tabel 2 Hasil uji Hg pada sampel air tawar dari sungai meureubo

\begin{tabular}{clccc}
\hline \multirow{2}{*}{ Kode } & \multirow{2}{*}{ Nama tempat } & \multicolumn{2}{c}{ Cemaran Merkuri $(\mathrm{Hg})$} & \multirow{2}{*}{ Frekuensi } \\
\cline { 3 - 3 } Sampel & & Negatif & Positif & \\
\hline Stasiun 1 & Rantau Panjang & & $\sqrt{ }$ & 0,0005085 \\
Stasiun 2 & Pasie Pinang & & $\sqrt{ }$ & 0,0001792 \\
Stasiun 3 & Pasie Aceh & & $\sqrt{ }$ & 0,0006711 \\
\hline
\end{tabular}

Kandungan merkuri $(\mathrm{Hg})$ pada semua titik stasiun penelitian terdeteksi, hal ini membuktikan bahwa perairan Krueng Meureubo terdapat logam berat. Namun, kandungan merkuri (Hg) di perairan Kreung Meureubo masih sesuai baku mutu yang ditetapkan WHO tahun 2008 yaitu 0,08 ppm. Pada setiap stasiun juga dilakukan pengecekan terhadap kualitas air. Parameter yang dikaji diantaranya adalah suhu, $\mathrm{pH}$, dan DO. Dari hasil kajian terhadap kualitas air dapat dilihat pada Tabel 3.

Tabel 3 Parameter Kualitas Air

\begin{tabular}{cccc}
\hline Kode & \multicolumn{3}{c}{ Parameter Kualitas Air } \\
\cline { 2 - 4 } Sampel & Suhu & $\mathrm{pH}$ & $\mathrm{DO}$ \\
\hline Stasiun 1 & $25{ }^{\circ} \mathrm{C}$ & 7 & $9.24(\mathrm{mg} / \mathrm{l})$ \\
\hline Stasiun 2 & $26{ }^{\circ} \mathrm{C}$ & 7 & $8.21(\mathrm{mg} / \mathrm{l})$ \\
\hline Stasiun 3 & $26{ }^{\circ} \mathrm{C}$ & 7 & $8.44(\mathrm{mg} / \mathrm{l})$ \\
\hline
\end{tabular}

Suhu merupakan salah satu parameter penting bagi kehidupan organisme disungai maupun lautan, karena banyak berperan dalam metabolisme, perkembangbiakan dan proses fisiologis organisme (Effendi, 2003). Adapun suhu di Krueng Meurebo sebesar $26{ }^{\circ} \mathrm{C}$, termasuk pada kategori suhu yang cukup baik untuk mendukung kehidupan yang ada di dalamnya. Namun demikian suhu yang tinggi akan memberikan efek negatif, disebabkan energi akan lebih banyak digunakan untuk mempertahankan hidup dari pada untuk pertumbuhan atau berkembang biak (Marganof, 2007). Nilai pH Kreung Meureubo relatif sama yaitu 7. Variasi pH berada pada keadaan 
stabil yang berarti biota-biota diperairan Kreung Meureubo masih dapat melakukan hidupnya secara normal.

Kandungan oksigen terlarut di stasiun I sebesar $9.24 \mathrm{mg} / \mathrm{l}$, stasiun II $8.24 \mathrm{mg} / \mathrm{l}$, stasiun III $8.44 \mathrm{mg} / \mathrm{l}$. Kandungan oksigen terlarut minimum $2 \mathrm{mg} / \mathrm{l}$, oksigen terlarut sudah cukup mendukung kehidupan organisme perairan secara normal. Berdasarkan data yang diperoleh, untuk sampel air pada stasiun I memiliki nilai DO yang lebih tinggi dari pada nilai DO stasiun II dan stasiun III, karna pada pada stasiun I air berintraksi dengan oksigen dari udara secara tidak langsung, dikarenakan adanya tumbuhtumbuhan atau sampah dipermukaan air tersebut.

Hasil penelitian kerang (Anodonta sp.), air tawar tingkat persentase merkuri ( $\mathrm{Hg}$ ) pada stasiun III (49\%) lebih tinggi dibandingkan dengan stasiun I (38\%) dan stasiun II (13\%). Tingginya persentase logam berat merkuri $(\mathrm{Hg})$ pada stasiun III Pasie Aceh, disebabkan karena aliran sungai Meurebo berada pada lokasi yang lebih hulu dibandingkan stasiun lainnya . Daerah hulu aliran Krueng Meureubo terdapat kegiatan pengolahan tambang emas tradisonal dan juga penambangan batu bara.

Pada riset ini, jumlah sampel kerang air (Anodonta sp) yang dianalisis berjumlah 15 berasal dari 3 stasiun. Sedangkan sampel air terdiri dari 3 botol air yang bersumber dari stasiun yang sama dengan kerang air (Anodonta sp) di kawasan Krueng Meureubo. Dari tabel 1 diatas dapat diketahui bahwa dari 3 stasiun sampel kerang air tawar (Anodonta $\mathrm{sp}$ ) dan sampel air tawar teridentifikasi mengandung merkuri ( $\mathrm{Hg}$ ). Adapun besarnya kadar merkuri yang terkandung pada masing-masing sampel tersebut dapat diketahui melalui metode AAS dan langsung terbaca pada layar monitor AAS tersebut.

Hasil observasi terhadap kerang air tawar (Anodonta sp) dan parameter kualitas air dari 3 stasiun yang berada di kawasan sub DAS Krueng Meureubo, di antaranya terindetifikasi positif mengandung merkuri $(\mathrm{Hg})$ yaitu dengan kode sampel RP, PP dan PA. Kandungan merkuri $(\mathrm{Hg})$ tersebut diasumsikan berasal dari penambang emas tradisional yang berada disekitar kawasan Krueng Meureubo. Merkuri digunakan sebagai bahan untuk memisahkan antara emas dengan bahan material lainnya. selain kandungan emas. Penggunaan bahan tambahan merkuri $(\mathrm{Hg})$ dapat merugikan kesehatan dan lingkungan apabila pengelolaan limbahnya tidak ditanggulangi secara baik. Hal seperti ini diperparah oleh rendahnya pengetahuan masyarakat dalam mengolah bahan merkuri (Hg) (Wahyu et al. 2008). Kebiasaan masyarakat dalam mengolah tambang emas, belum beroritentasi pada keamanan dan kelestarian lingkungan. Pada umumnya, masyarakat penambang emas lebih berorientasi pada berapa besarnya keuntungan yang diperoleh, sehingga aspek utama dalam memelihara kesehatan diri dan lingkungan terabaikan. Pengetahuan masyarakat dalam mengelola emas masih terbatas. Sedangkan, keracunan dan pencemaran lingkungan diantaranya disebabkan oleh kelalaian dan ketidaktahuan masyarakat dalam pengolahan usaha tambang tersebut (Widodo, 2006).

Wulandari et al. (2004) menyatakan bahwa pola pencemaran logam berat pada spesies perairan bersifat unik untuk setiap jenis logam berat dan untuk setiap spesies perairan yang dicemarinya. Logam berat dengan massa atom lebih kecil umumnya lebih 
cepat menyebar dan mencemari dari pada logam berat dengan massa atom lebih besar. Spesies perairan yang bersifat pasif (ikan demersal, ikan karang, dan jenis kerang lainnya) juga lebih mudah mengakumulasi logam berat lebih banyak dari pada spesies yang bersifat aktif dan bermigrasi pada areal yang luas. Dalam kaitan ini, maka kegiatan tersebut sudah tidak aman untuk dilakukan, selain karena logam berat tersebut mengganggu perkembangbiakan, secara ekonomis, juga dapat menurunkan kualitas tangkapan masyarakat pencari kerang air tawar (Anodonta sp). Status tercemar ( $\mathrm{Hg}$ ) tersebut juga memberi indikasi bahwa beban limbah yang dibuang dari industri yang bermuara di sungai telah berada pada taraf yang membahayakan (Murthy, 2009),

Mustaruddin (2011) menyatakan bahwa merkuri termasuk bahan pencemar yang paling berbahaya dalam kegiatan perikanan tangkap karena terus mengakumulasi hingga mencapai kondisi jenuh, menganggu perkembangbiakan kerang air tawar (Anodonta $s p$ ), dan menetap secara permanen di tubuh kerang air tawar (Anodonta $s p$ ), sehingga menurunkan mutu gizi dan berdampak degeneratif bila dikonsumsi. Direktorat Jenderal Pengawasan obat dan Makanan (POM) No. 03725/SK/VII/89 menetapkan batas maksimum cemaran logam berat dalam makanan, untuk merkuri $(\mathrm{Hg})$ adalah 0,5 ppm (Harizal, 2006). Sedangkan menurut Wahyu (2008) kadar maksimum $\mathrm{Hg}$ yang diizinkan dan boleh dikonsumsi pada berbagai jenis pangan adalah $0,1 \mathrm{ppm}$ dan pada air sungai sebesar 0,08 ppm. WHO (World Health Organization) 2011 menetapkan batasan maksimum yang lebih rendah yaitu 0,0001 ppm untuk air dan batas maksimum cemaran logam berat dalam makanan $0,01 \mathrm{ppm}$.

Toksisitas merkuri pada manusia dibedakan menurut bentuk senyawa $\mathrm{Hg}$ yaitu inorganik dan organik. Keracunan inorganik $\mathrm{Hg}$ ditandai dengan gejala tremor pada orang dewasa, kemudian berlanjut dengan tremor pada otot muka, yang kemudian merambat ke jari-jari dan tangan. Bila keracunan berlanjut tremor terjadi pada lidah, berbicara terbata-bata, berjalan terlihat kaku dan hilang keseimbangan. Selain toksisitas $\mathrm{Hg}$ inorganik, bentuk $\mathrm{Hg}$ organik juga menimbulkan toksisitas yang sangat berbahaya, contoh kasus toksisitas metil merkuri adalah kasus "minamata disease" yang menimpabaik pada orang dewasa maupun anak kecil yang terjadi di Jepang . Sistem saraf pusat adalah target organ dari toksisitas metil merkuri tersebut dengan gejala yang ditimbulkan sebagai berikut:

1. Gangguan saraf sensorik; paraesthesia, kepekaan menurun dan sulit menggerakkan jari tangan dan kaki, penglihatan menyempit, daya pendengaran menurun, serta rasa nyeri pada lengan dan paha.

2. Gangguan saraf motorik; lemah, sulit berdiri, mudah jatuh, ataksia, tremor, gerakan lambat, dan sulit berbicara.

3. Gangguan lain; gangguan mental, sakit kepala, hipersalivasi (Darmono, 2001).

Bedasarkan Keputusan Menteri Kependudukan dan Lingkungan Hidup No. 02/MENKLH/1988 yang dimaksud dengan pencemaran adalah masuk atau dimasukannya makhluk hidup, zat energi, dan/atau komponen lain ke dalam air atau udara, atau berubahnya tatanan (komposisi) air atau udara oleh kegiatan manusia atau 
proses alam, sehingga kualitas air atau udara menjadi kurang atau tidak dapat berfungsi lagi sesuai dengan peruntukannya (Kristanto, 2002). Dalam hal ini bagi sebagai pelaku industri tambang emas tradisional agar tidak membuang limbah industri khususnya logam berat merkuri (Hg) di DAS Kawasan Kecamatan Meureubo dan bagi masyarakat konsumen harus berhati-hati terhadap adanya pencemaran bahan logam berat merkuri (Hg) yang terkandung pada jenis kerang air tawar tersebut (Kristanto, 2002).

\section{Kesimpulan}

Dari hasil penelitian yang telah dilakukan dapat disimpulkan :

1. Kandungan logam berat merkuri $(\mathrm{Hg})$ total pada sampel kerang air tawar (Anodonta sp) pada stasiun RP 0,074 ppm, PP 0,042 ppm, dan PA 0,304 ppm.

2. Kandungan logam berat merkuri $(\mathrm{Hg})$ total pada sampel air tawar pada stasiun RP 0,0005085 mg/l, PP 0,0001792 mg/l dan PA 0,0006711 mg/l.

3. Kandungan logam berat merkuri pada kerang air tawar di stasiun III Pasie Aceh telah melampaui baku mutu untuk dikonsumsi atau melewati batas baku mutu 0,1 ppm yang telah ditetapkan, sedangkan pada stasiun I Rantau panjang dan stasiun II Pasie Pinang masih di bawah batas baku mutu yang telah ditetapkan sebesar 0,1 ppm.

4. Kandungan logam berat merkuri pada sampel air tawar di perairan Krueng Meureubo belum melampaui batas baku mutu untuk layak dikonsumsi yang telah ditetapkan WHO sebesar 0,08 ppm untuk air tawar.

\section{Daftar Pustaka}

Darmono (2001). Lingkungan Hidup dan Pencemaran, Hubungannya dengan Toksikologi Senyawa Logam. Universitas Indonesia (UI) Press. Jakarta.

Effendi H. (2003). Telaah Kualitas Air Bagi Pengelolaan Sumber Daya dan Lingkungan Perairan. Yogyakarta: Percetakan Kanisius.

Ermin K W, Andayani W, dan Sumartono A. (2008). Metil Merkuri dalam Kerang Hijau (Mytilus viridis L.)dari Pasar Pelelangan Ikan Muara Angke: Sebelum dan Setelah Pemasakan. Indonesian Journal of Chemistry, 9 (1), 77 - 83.

Fauziah A R, Boedi S R, dan Yudi C. (2012). Korelasi ukuran kerang darah (Anadara Granosa) dengan konsentrasi logam berat merkuri (Hg) di Muara Sungai Ketingan, Sidoarjo, Jawa Timur. Journal of Marine and Coastal Science, 1(1): $34-44$.

Harizal (2006). Studi Konsentrasi Logam Berat Merkuri (Hg) Pada Kerang Hijau (Perna Viridis l) Sebagai Bio Monitoring Pencemaran Di perairan Pantai. [Skripsi]. Manajemen Sumber Daya Perairan, Universitas Brawijaya. Malang.

Hutagalung H P. (1985). Raksa (Hg). X, 3. Lembaga Oseanografi Nasional Lembaga Ilmu Pengetahuan Indonesia, 9 dan 102. Jakarta.

Kristanto P. (2002). Ekologi Industri. Andi offset. Yogyakarta.

Marganof (2007). Model Pengendalian Pencemaran Perairan Di Danau Maninjau Sumatra Barat. Laporan hasil penelitian, Sekolah Pasca Sarjana IPB Bogor. 
Murthy L N. (2009). Monitoring of cadmium accumulation in cephalopods processed in Gujarat Coast. Journal of Asian Fisheries Science, 22:319-330.

Mustaruddin N. (2011). Karakteristik perairan dalam kaitannya dengan pengembangan usaha perikanan pelagis besar di Kabupaten Aceh Jaya. Buletin PSP, 20.69.

Purnawan S, Sikanna R, Prismawiryanti. (2013). Distribusi logam merkuri pada sedimen laut di sekitar Muara Sungai Poboya. Jurnal of Natural Science, 2 (1): 18-24 (ISSN: 2338-0950).

Sartika A. (2002). Profil Kandungan Logam Berat Merkuri (Hg) dan Tembaga (Cu) dalam Kupang Beras (Tellina versicolor) (Studi Kasus pada Kupang Beras yang dipasarkan di Keraton Pasuruan). [Skripsi]. Pendidikan Kimia, Fakultas Matematika dan Ilmu Pengetahuan Alam, Universitas Jember.

Suhendryatna (2001). Bioremoval Logam Berat dengan Menggunakan Mikroorganisme Suatu Kajian Kepustakaan (Heavy Metal Bioremeval by Micriorganisme: A Literatur Study). di sampaikan pada Seminar On-Air Bioteknologi untuk Indonesia Abad 21, 1-14 Februari 2001, Seminar Forum PPI Tokyo Institute Of Technology.

Surat Keputusan Menteri (1998). Keputusan Menteri Negara Kependudukan Dan Lingkungan Hidup Nomor: Kep-02/Menklh/I/1988. Pedoman Penetapan Baku Mutu Lingkungan. Jakarta.

Umar M T. (2001). Kandungan logam berat tembaga $(\mathrm{Cu})$ pada air, sedimen, dan kerang Marcia Sp. di Teluk Parepare Sulawesi Selatan. Jurnal Natur Indonesia, 2(2).

Wahyu W, Astiana S, Raymond J R. (2008). Efek Toksin Logam. Bandung.

WHO (World Health Organization). 2011. Guidelines for drinking-water quality, fourth edition. ISBN 978924154815 1. Printed in Malta.

Widhiyatna D. (2005). Pendataan penyebaran merkuri akibat usaha pertambangan emas di Daerah Tasikmalaya, Propinsi Jawa Barat. A Review. Indonesian Journal of Chemistry, 12 (1): 51-53.

Widodo (2006). Optimalisasi Pengolahan Bijih Emas Cara Amalgamasi di Kecamatan Waluran Kabupaten Sukabumi, UPT Loka Uji Teknik Penambangan Jampang Kulon - LIPI Sukabumi, h.4-17.

Wulandari E, Herawati Y, dan Arfiati D. (2004). Kandungan logam berat Pb pada air laut dan tiram Saccostrea glomerata sebagai bioindikator kualitas perairan Prigi, Trenggalek, Jawa Timur. Jurnal Penelitian Perikanan, 1: 10-14. 